\title{
PENGELOLAAN WAKAF TANAH PRODUKTIF: Studi Kasus Nazhir Badan Kesejahteraan Masjid (BKM) Kota Semarang dan Yayasan Muslimin Kota Pekalongan
}

\author{
Ahmad Furqon \\ Universitas Islam Negeri (UIN) Walisongo, Semarang \\ e-mail: ahmadfurqonws@gmail.com
}

\begin{abstract}
Mosque Welfare Agency (BKM) Semarang and Pekalongan Muslim Foundation (YKMP) is a nāzir of productive waqf land. Management of waqf performed by BKM Semarang has not given the expected results, while the management of waqf by YMKP has given results as planned. The main question in this research is what are the factors of success and failures of both institutions in managing of productive land waqf? The answers are measured using two parameters: 1) The investment strategy by BKM Semarang and YMKP; 2) The organization's management of nāzir of YMKP and BKM? This is a qualitative research with case study approach. Data is collected using observation, interview, and documentation. The methode of analysis is the comparative descriptive. The findings of this research are: 1) Investment of land waqf performed by BKM Semarang unproductive, while investment and distribution of land waqf performed by YMKP productive. 2) The organization's management of BKM in each function is not effective. While the organization's management of YMKP is effective.
\end{abstract}

[]

Badan Kesejahteraan Masjid (BKM) Kota Semarang dan Yayasan Muslimin Kota Pekalongan (YKMP) adalah nazhir badan hukum yang mengelola tanah wakaf secara produktif. Pengelolaan wakaf yang dilakukan oleh BKM Kota Semarang belum memberikan hasil seperti yang diharapkan, sedangkan pengelolaan wakaf oleh YMKP telah memberikan hasil seperti yang direncanakan. Pertanyaan utama dalam penelitian ini adalah apa faktor keberhasilan dan ketidakberhasilan dari kedua lembaga tersebut dalam mengelola wakaf tanah produktif? Jawaban pertanyaan di atas diukur menggunakan dua parameter: 1) Strategi investasi BKM Kota Semarang dan YKMP; 2) Manajemen organisasi kenazhiran BKM Kota Semarang dan YKMP. Penelitian kualitatif ini menggunakan pendekatan studi kasus. Pengumpulan data dilakukan menggunakan teknik observasi, wawancara, dan dokumentasi. Penelitian dianalisis dengan metode deskriptif komparatif. Temuan penelitian ini adalah: 1) Investasi tanah wakaf yang dilakukan oleh BKM Kota Semarang tidak produktif sedangkan Investasi dan pendistribusian hasil yang dilakukan oleh YMKP produktif. 2) Manajemen organisasi BKM Kota Semarang pada tiap-tiap fungsinya tidak berjalan efektif. Sedangkan manajemen organisasi YMKP telah berjalan cukup efektif.

Keywords: $\quad$ wakaf produktif; nazhir; Badan Kesejahteraan Masjid (BKM);

Yayasan Muslimin Kota Pekalongan (YMKP) 
Ahmad Furqon

\section{Pendahuluan}

Badan Kesejahteraan Masjid (BKM) Kota Semarang adalah nazhir badan hukum yang mengelola tanah wakaf secara produktif. Berdasarkan Laporan BKM Kota Semarang tahun 2010, tanah wakaf yang dikelola BKM Kota Semarang memiliki luas $\pm 1.316 .773 \mathrm{~m}^{2}( \pm 131$ ha.).

Penunjukkan BKM Kota Semarang sebagai nazhir wakaf adalah berdasarkan ayat (3) KMA No.92 Tahun 1962.1 Akan tetapi status BKM Kota Semarang sebagai nazhir wakaf banyak digugat oleh masyarakat yang tidak puas dengan kinerja BKM Kota Semarang selaku nazhir wakaf. KH. Sahal Mahfudz (alm.) sempat melontarkan gagasan agar struktur BKM secara kelembagaan dirombak, apabila tidak mungkin dibubarkan. Menurutnya BKM tidak mensejahterakan masjid-masjid yang ada dan tidak transparan dalam pengelolaan harta yang dimiliki. ${ }^{2}$ Demikian juga Ali Mufiz, Ketua BP MAJT periode 20082013, ${ }^{3}$ menyatakan ketidakpuasan terhadap pengelolaan wakaf yang dilakukan oleh BKM Kota Semarang. Menurutnya BKM lebih baik menyerahkan secara utuh proses pengelolaan tanah wakaf kepada pihak swasta.

Yayasan Muslimin Kota Pekalongan -selanjutnya disebut dengan YMKP-, juga merupakan nazhir badan hukum yang mengelola tanah wakaf secara produktif. Tanah wakaf yang dikelola YMKP tidak seluas tanah wakaf yang dikelola oleh BKM Kota Semarang. YMKP hanya mengelola tanah wakaf seluas $1.336 \mathrm{~m}^{2}$. Pengelolaan tanah wakaf yang dilakukan oleh YMKP dipandang berhasil. Menurut Amirudin Darori ${ }^{4}$ selaku Kasi Pengembangan Ekonomi Wakaf pada Subdit Pemberdayaan Wakaf, YMKP berhasil mengelola harta wakaf, dengan indikator tercapainya BEP (Break Event Point) sesuai yang direncanakan, dan hasilnya dapat didistribusikan kepada mawqūf'alayh.

Belum berhasilnya BKM Kota Semarang, dan berhasilnya YMKP dalam mengelola wakaf tanah produktif, menimbulkan pertanyaan mengapa BKM Kota

\footnotetext{
1KMA No. 92 Tahun 1962 berbunyi: “Sebagai Nadzir dari masjid-masjid wakaf tersebut ditunjuk pengurus Kas Masjid (PKM) di Semarang, Kendal, Kaliwungu dan Demak"

2http://www.suaramerdeka.com, diakses tanggal 22 Juli 2012

3Wawancara, tanggal 15 Mei 2012.

4Wawancara, tanggal 23 Mei 2011.
}

94 || Volume 26, Nomor 1, April 2016

AL-AHKAM p-ISSN: 0854-4603; e-ISSN: 2502-3209 
Semarang belum berhasil mengelola tanah wakaf produktif sedangkan YMKP telah berhasil mengelolanya.

Untuk menjawab pertanyaan tersebut, maka perlu dilihat sisi manajemen organisasi kenazhiran, dan investasi wakaf yang dilakukan oleh kedua nazhir badan hukum ini. Rumusan masalah dalam penelitian ini adalah sebagai berikut: 1) Bagaimana efektifitas manajemen organisasi kenazhiran BKM Kota Semarang dan YMKP? 2) Bagaimana produktivitas investasi wakaf tanah produktif yang dilakukan oleh BKM Kota Semarang dan YMKP?

Penelitian ini adalah penelitian studi kasus. Adapun pendekatan yang digunakan dalam penelitian ini adalah pendekatan manajemen. Teknik pengumpulan data dilakukan melalui observasi, wawancara, dan dokumentasi. Data telah terkumpul kemudian dianalisis secara deskriptif.

\section{Konsep Manajemen Wakaf}

\section{Manajemen dan Fungsi-fungsinya}

Manajemen menurut Stoner ${ }^{5}$ adalah proses membuat perencanaan, mengorganisasikan, memimpin, dan mengendalikan berbagai usaha dari anggota organisasi dan menggunakan semua sumber daya organisasi untuk mencapai tujuan.

Ada empat tahapan dasar dalam perencanaan yang semua kegiatan perencanaan pada dasarnya melalui empat tahap tersebut, yaitu: a) Menetapkan tujuan atau serangkaian tujuan. Satu cara untuk menulis tujuan yang efektif adalah dengan menggunakan pedoman SMART. SMART adalah singkatan dari Specific (spesifik), Measurable (terukur), Attainable (dapat dicapai), Realistic (realistis) dan Timely (tepat waktu). ${ }^{6}$ b) Merumuskan keadaan saat ini. c) Mengidentifikasi segala kemudahan dan hambatan. d) Mengembangkan rencana atau serangkaian kegiatan untuk pencapaian tujuan.7

5James A.F. Stoner, dkk, Manajemen, alih bahasa Alexander Sindoro, Jilid I Jakarta: PT. Prenhallindo, 1996), h. 10.

${ }^{6}$ Chuck Williams, Manajemen (terj.) (Jakarta: Salemba Empat, 2001), h. 149.

${ }^{7}$ Handoko, T.Hani, dkk, Manajemen dalam Berbagai Perspektif (Jakarta: Erlangga, 2012), h. 79-80. 
Berhubungan dengan pengorganisasian, Weber sebagaimana dikutip oleh Stoner menyebutkan karakteristik lembaga birokrasi yang ideal, yaitu spesialisasi tugas, penunjukkan berdasarkan penilaian, menyediakan peluang meniti karir untuk anggota, rutinitas aktivitas dan iklim organisasi yang rasional. ${ }^{8}$ Sejalan dengan Weber, Kahf mengusulkan organisasi wakaf dikelola per-aset wakaf, dengan melibatkan SDM lokal dan memiliki masa tugas yang jelas. ${ }^{9}$

Al-Asyqar berdasarkan penelitiannya terhadap lembaga-lembaga charity di Barat mengusulkan struktur organisasi wakaf terdiri dari dua badan, yaitu Majelis Umanā' (nazhir), dan al-Idārah (badan pengelola atau pelaksana). Di bawah badan pengelola dan pelaksana ada devisi atau bagian, yaitu bagian hubungan masyarakat, dan bagian investasi. ${ }^{10}$

Sedangkan kepemimpinan adalah kemampuan seseorang untuk mempengaruhi, memotivasi, dan mengarahkan orang lain untuk mencapai tujuantujuan tertentu. Sedangkan pemimpin adalah seseorang yang memiliki pengetahuan dan kemampuan yang sesuai untuk memimpin sebuah kelompok dalam mencapai tujuannya. ${ }^{11}$

Para peneliti menyimpulkan kepemimpinan yang efektif adalah apabila seorang pemimpin melaksanakan dua fungsi, yaitu fungsi yang berhubungan dengan tugas atau memecahkan masalah dan fungsi memelihara kelompok atau sosial. ${ }^{12}$

Fungsi manajemen yang terakhir adalah pengawasan. Kadang juga disebut sebagai pengendalian, penilaian, koreksi atau penilaian. Pengawasan adalah kegiatan penelitian, pengamatan, dan pengukuran terhadap jalannya operasi berdasarkan rencana yang telah ditetapkan, penafsiran dan perbandingan hasil yang dicapai dengan standar yang diminta, melakukan tindakan koreksi

\footnotetext{
8Ibid., h. 2/16.
}

9Monzer Kahf, al-Waqf al-Islāmī, Tațawwuruh, Idāratuh, Tanmiyyatuh (Suriah: Dār al-Fikr, 2006), h. 313.

10'Usamah 'Umar al-Ashqar, Tațīr al-Mu'assasah al-Waqfiyyah al-Islāmiyyah fi Daw' al-Tajribah al-Khairiyyah al-Gharbiyyah (Kuwait: al-Amānah al-'Āmmah li 'IAwqāf, 2007), h. 130.

11James A. F. Stoner, dkk, Manajemen, jilid 1, h. 10.

12Ibid., jilid 2, h. 165. 
penyimpangan, dan perbandingan antara hasil (output) yang dicapai dengan masukan (input) yang digunakan.

\section{Efektivitas Manajemen Wakaf}

Dalam menilai tingkat keberhasilan manajemen wakaf, penelitian ini menggunakan konsep efektivitas Peter Drucker. Efektivitas adalah "melakukan sesuatu yang tepat". Kata efektivitas biasanya digandeng dengan kata efisiensi. Efisiensi adalah melakukan sesuatu dengan tepat. Efesiensi adalah konsep "input dan output". Seorang manajer yang efisien adalah seseorang yang mencapai output, atau hasil yang diukur dengan input (tenaga kerja, material, dan waktu) yang dipergunakan. Manajer yang efisien mampu meminimalkan biaya dan sumber daya yang diperlukan. Efektivitas sebaliknya, memilih sasaran yang tepat. Sebanyak apapun efisiensi, tidak akan mampu menutupi kekurangan efektivitas. Menurut Drucker sebagaimana yang dikutip oleh Stoner efektivitas merupakan kunci keberhasilan suatu organisasi. Sebelum melakukan kegiatan secara efisien, harus diyakini terlebih dahulu bahwa organisasi telah menemukan hal yang tepat untuk dilakukan ${ }^{13}$.

\section{Produktivitas Usaha}

Produktivitas usaha digunakan untuk menilai produktivitas pendanaan dan investasi yang telah dilakukan oleh kedua lembaga kenazhiran ini. Produktivitas berasal dari bahasa Inggris, product: result, outcome berkembang menjadi kata productive, yang berarti menghasilkan, dan productivity: having the ability make or create. Perkataan itu dipergunakan dibahasa Indonesia menjadi produktivitas yang berarti kekuatan atau kemampuan menghasilkan sesuatu. ${ }^{14}$

Menurut Siagian produktivitas kerja adalah kemampuan memperoleh manfaat sebesar-besarnya dari sarana dan prasarana yang tersedia dengan menghasilkan output yang optimal, kalau mungkin yang maksimal. Produktivitas merupakan rasio antara output yang dapat diukur (tangible output) dan

${ }^{13} \mathrm{Ibid.j}$,jlid 1, h. 9.

${ }^{14}$ Sedarmayanti, Pengembangan Kepribadian Pegawai (Bandung: Mandar Maju, 2004), h. 7. 
input yang dapat diukur (tangible input). Produktivitas merupakan suatu ukuran kinerja perusahaan yang menunjukkan seberapa baik pemanfaatan input menjadi output.15 Input merupakan segala bentuk sumber daya yang digunakan dalam produksi dan membentuk biaya produksi seperti tenaga kerja (manhours), material, energi, kapital yang meliputi peralatan dan mesin. ${ }^{16}$

\section{Manajemen Organisasi BKM Kota Semarang dan YMKP}

\section{Perencanaan Organisasi}

BKM Kota Semarang dan YMKP sama-sama telah melakukan perencanaan. Rencana program kerja yang dibuat oleh BKM Kota Semarang lebih detil daripada yang dibuat oleh YMKP. Menurut Williams, dalam membuat perencanaan dapat berpedoman pada SMART. SMART adalah singkatan dari Specific (spesifik), Measurable (terukur), Attainable (dapat dicapai), Realistic (realistis) dan Timely (tepat waktu).17

Program kerja yang dibuat oleh BKM Kota Semarang telah memenuhi unsur specific, measurable, akan tetapi belum memenuhi unsur attainable, realistic, dan timely. Unsur timely tidak terpenuhi karena tidak memberikan batasan waktu yang pasti selesainya program kerja tersebut. Sedangkan untuk attainable dan realistic program kerja tersebut. Perlu didekati dengan melihat sisi kekuatan, kelemahan, peluang, dan ancaman dari tiap-tiap rencana program kegiatan tersebut.

Kegiatan-kegiatan BKM Kota Semarang yang belum bisa terlaksana karena ketiadaan dana, menjadi tidak realistis kalau direncanakan. Akan lebih baik direncanakan terlebih dahulu cara pendanaan untuk program-program tersebut. Begitu juga program mengontrakkan tanah pertanian, tidak dapat dilaksanakan kalau permasalahan tanah dengan penggarap yang mengklaim memiliki tidak diselesaikan terlebih dahulu. Maka untuk permasalahan ini,

\footnotetext{
15Sondang P. Siagian, Organisasi Kepemimpinan dan Perilaku Administrasi (Jakarta: CV. Haji Mas Agung, 1998), h. 15.

16Muchdarsyah Sinungan, Produktivitas apa dan Bagaimana (Jakarta: Bumi, 2000), h. 23.

17Chuck Williams, Manajemen (terj.), h.149.
} 
yang perlu direncakana adalah program pembebasan tanah tersebut atau sertifikasi terhadap tanah wakaf yang belum bersertifikat.

Permasalahan ketiadaan dana merupakan problem tersendiri sebagai lembaga semi resmi seperti BKM Kota Semarang. Karena sebagai lembaga semi resmi, BKM Kota Semarang tidak bisa mengajukan anggaran rutin, kecuali mendapat anggaran dari Seksi Urusan Agama Islam (Urais) atau anggaran Kepala Kantor Kemenag Kota, yang ex-officio adalah kepala BKM Kota Semarang. Untuk melakukan penggalangan dana publik atau masyarakat, BKM terbentur dengan statusnya sebagai lembaga Pemerintah yang melakukan pelayanan publik bukan lembaga profit.

Rencana program kerja YMKP telah memenuhi unsur specific, measurable, attainable, realistic, timely, hal tersebut dibuktikan dengan terlaksananya program-program yang direncanakan, kecuali penambahan kamar hotel, yang belum terlaksana karena masih digunakan sebagai TK. Bakti. Akan tetapi pada tahun 2014 telah dibelikan tanah seluas $1320 \mathrm{~m}^{2}$ untuk pembangunan TK Bakti, sehingga diharapkan pada tahun 2015, penambahan kamar hotel bisa terlaksana.

\section{Pengorganisasian}

BKM adalah nazhir yang dibentuk oleh Pemerintah ${ }^{18}$. Dalam Pasal 2 PMA No. 54 Tahun 2006 tentang Susunan dan Tata Kerja BKM, disebutkan bahwa: "BKM adalah lembaga semi resmi yang dibentuk oleh Kementerian Agama, untuk meningkatkan peranan dan fungsi masjid sebagai tempat ibadah dan sarana pembinaan umat Islam"

Dari pernyataan Pasal 2 tersebut menunjukkan bahwa BKM adalah lembaga Pemerintah yang tidak hanya mengurusi masalah wakaf saja akan tetapi juga hal-hal yang berkaitan dengan pengelolaan masjid. Hal tersebut semakin jelas apabila melihat tujuan dari BKM, sebagaimana pasal 6 PMA No.54 tahun 2006 yang berbunyi: "BKM bertujuan meningkatkan kesejahteraan masjid serta tempat ibadah umat Islam lainnya atas dasar takwa melalui peningkatan manajemen (idārah), kemakmuran (imārah), dan pemeliharaan (ri'āyah)".

\footnotetext{
18 Wawancara dengan Arifin (Pengurus BKM Kota Semarang) tanggal 17 Februari 2012.
} 
Orang-orang yang terlibat dalam kepengurusan BKM Kota Semarang, semuanya adalah berasal dari internal Kementerian Agama Kota Semarang, tidak melibatkan unsur luar atau masyarakat.

YMKP adalah nazhir organisasi yang telah disahkan berdasarkan Surat Pengesahan Nazhir No. W.5.a/I/VI/2006 dari Kepala Kantor Urusan Agama Kecamatan Pekalongan Barat selaku Pejabat Pembuat Akta Ikrar Wakaf. YMKP merupakan nazhir swasta yang tidak memiliki struktur ke atas, ataupun dengan institusi Pemerintah.

Menurut Weber ada tiga kriteria birokrasi yang baik, yaitu adanya spesialisasi tugas, penunjukkan berdasarkan penilaian, dan menyediakan ruang untuk meniti karir. Terkait dengan spesialisasi tugas, Kahf sejalan dengan dengan Weber, menurut Kahf, lembaga wakaf harus menerapkan pengelolaan dhurriyat (per-aset wakaf), memanfaatkan SDM lokal (mahalliyah).

\section{Spesialisasi Tugas}

Terkait dengan spesialisasi tugas, BKM Kota Semarang tidak melakukan spesialisasi tugas. Pengurus BKM Kota Semarang adalah pengurus yang memiliki rangkap jabatan. Ketua BKM yang ex officio Kepala Kantor Kementerian Agama dan Kepala Harian BKM yang ex officio Kasi Urais menunjukkan adanya rangkap jabatan dalam struktur kepengurusan BKM. Sebenarnya bukan hanya pada dua level tersebut saja akan tetapi juga pada bidang-bidang yang ada dalam struktur organisasi BKM. Karena dalam pasal 10 PMA No. 54 tahun 2006 menyebutkan bahwa jabatan sekretaris dan bendahara dijabat oleh pegawai dari seksi Urais, sedangkan jabatan ketua bidang dan anggota dijabat oleh pegawai Kemenag Kota.

Sehingga dalam pengelolaan wakaf di BKM Kota Semarang dilakukan oleh person-person yang telah memiliki tugas utama sebagai PNS Kementerian Agama, yang mendapat tugas tambahan sebagai pengurus BKM. Sedangkan kerja pengurus BKM itu sendiri tidak hanya fokus pada pengelolaaan wakaf saja, akan juga pada bidang lain yang terkait dengan kesejahteraan masjid. Sehingga yang terjadi dalam pengelolaan wakaf di BKM Kota Semarang adalah dilakukan oleh person-person yang rangkap jabatan atau tugas. Pengelolaan 
wakaf yang dilakukan secara rangkap, menjadikan pengelolaan tidak effisien dan maksimal karena waktu yang dimiliki terkadang habis untuk mengurus tugas utama, apalagi bila rangkap jabatan secara berlapis-lapis.

Keterbatasan SDM dirasakan oleh Ketua BKM Kota Semarang, ia mengatakan:

"Tidak mungkin staf saya ke sawah, ada yang pensiun, dan ada yang mutasi. Saya tidak ingin staf saya nantinya ditanya malaikat, dia di sini sebagai pegawai, tapi tidak masuk karena sering ke sawah, BKM inikan tugas sampingan, tupoksinya sebagai pegawai, karena itu tidak boleh, karena itu masih jam tugas. Intinya, kalau struktur organisasi kesulitan"19

Dapat dipahami dari pernyataan Taufik Rahman, bahwa struktur organisasi BKM Kota Semarang mengalami kesulitan dalam mengelola tanah wakaf yang demikian luas, karena jumlah pengurus yang terbatas, dan masingmasing telah memiliki tupoksinya.

YMKP dalam mengelola Islamic Business Center menerapkan spesialisasi pengelolaan, yaitu dengan menunjuk pengelola bagi tiap-tiap unit wakaf produktif. Untuk pengelolaan Hotel Syariah, YMKP membentuk pengelola hotel. Manajer dipilih satu tahun sekali, alasannya adalah untuk peremajaan, agar tidak bosan, dan agar kinerja manajer tetap bisa dikontrol. Dalam pengelolaan hotel YMKP berperan sebagai pengawas, dan pembina. Pengelola Hotel berkewajiban melaporkan perkembangan pengelolaan kepada pengurus YMKP.

Sedangkan untuk ruko dan pusat kuliner dikelola langsung oleh pengurus YMKP. Ruko dan pusat kuliner dikelola dalam bentuk disewakan sehingga tidak memperlukan perhatian khusus. Selain itu unit-unit usaha produktif tersebut berada dalam satu lokasi dan masih sedikit jumlahnya, sehingga masih mudah bagi YMKP untuk mengelola dan mengembangkannya.

\section{Penunjukan Berdasarkan Penilaian}

BKM Kota Semarang menyeleksi dan merekrut pengurusnya tidak didasarkan pada standar kompetensi dan keahlian yang dimiliki, akan tetapi

19Wawancara dengan Taufik Rahman, tanggal 8 Agustus 2012. 
Ahmad Furqon

berdasarkan jabatan struktural yang dipegang. Hal tersebut disampaikan oleh Taufik Rahman, dengan mengatakan:

"BKM itu nazhir wakaf organisasi yang berpusat di Jakarta dan jabatannya adalah ex officio. Di pusat dipimpin oleh Dirjen Bimas Islam sebagai ketua BKM pusat, dan ketua hariannya adalah Direktur Urais. Ketua BKM provinsi adalah Kepala Kanwil, dan ketua hariannya adalah Kabid Urais. Kabupaten/kota, ketuanya adalah Kakankemenag, dan ketua hariannya Kasi Urais, sampai Kecamatan kepalanya KUA"20

Tercermin dari perkataan Taufik Rahman bahwa penunjukan pengurus BKM didasarkan pada statusnya sebagai pegawai di lingkungan Kemenag Kota Semarang dan jabatan struktural yang disandangnya. Seorang Kepala Kantor Kemenag Kota Semarang adalah otomatis sebagai Kepala BKM Kota Semarang, sedangkan Kepala Sekasi Urusan Agama Islam (Urais) adalah otomatis sebagai Ketua Harian BKM Kota Semarang.

Pemilihan nazhir di YMKP juga tidak berdasarkan pada pertimbangan keahlian, akan tetapi karena berdasarkan hubungan emosional dengan YMKP, karena masih merupakan keluarga besar Masyumi. Akan tetapi faktor kepribadian, tetap menjadi penilaian dalam memilih pengurus YMKP, yaitu yang memiliki jiwa amanah dan keikhlasan dalam bekerja.

Ada juga pertimbangan kompetensi atau penguasaan terhadap bidang usaha produktif, akan tetapi tidak dilakukan seleksi secara formal untuk mengetahui kompetensi tersebut, lebih melihat pada latar belakang pendidikan dan profesi para pengurus tersebut.21 Beberapa nazhir YMKP adalah wirausahawan. Dari 5 orang nazhir yang tertera dalam Akta Ikrar Wakaf, 4 (empat) orang adalah wirausahawan, sedangkan 1 (satu) orang berprofesi sebagai guru. Bapak Amrizal Yasmin misalnya, beliau adalah ketua Ikatan Paguyuban Pedagang Batik Pasar Sentono Pekalongan. Nofel selain memiliki usaha batik juga sorang kontraktor, Nanang Abdullah berprofesi sebagai pengusaha batik. Profesi dan pengalaman yang mereka miliki ikut mewarnai pengelolaan wakaf produktif yang dilakukan oleh YMKP.

20Wawancara dengan Taufik Rahman, tanggal 8 Agustus 2012.

21Wawancara dengan Aisyah, tanggal 8 Januari 2012.

102 || Volume 26, Nomor 1, April 2016

AL-AHKAM p-ISSN: 0854-4603; e-ISSN: 2502-3209 
Terkait dengan karyawan yang bekerja pada wakaf produktif yang dikelola oleh YMKP, seperti di hotel, YMKP mengakui bahwa rekrutmen pegawai tidak didasarkan pada penilaian kompetensi akan tetapi lebih pada faktor kemanusiaan. Sehingga beberapa karyawan ada yang berlatar belakang pendidikan yang rendah. Ada yang hanya tamatan SD, kemudian ditempatkan di kuliner. Ada yang sebelumnya menjadi kuli bangunan, kemudian diangkat menjadi karyawan. Pada posisi resepsionis ada yang hanya tamatan SMP. YMKP memang belum membuat standar kualifikasi karyawan. ${ }^{22}$

\section{Ruang Meniti Karir bagi Anggota}

Kepemimpinan di BKM Kota Semarang dipilih karena sebab jabatan yang dimilikinya (ex officio). Karenanya tidak ada ruang untuk meniti karir bagi anggota. Hal tersebut juga dikeluhkan oleh beberapa pengurus, yang merasa ada orang yang memiliki kompetensi dan pengetahuan tentang pengelolaan wakaf akan tetapi tidak diberi tanggung jawab untuk mengelolanya, justru yang diberi tanggung jawab orang yang tidak memiliki kompetensi dan pengetahuan tentang tanah wakaf BKM.

Selain itu, karena pengurus BKM adalah pegawai struktural, maka bila terjadi mutasi atau pindah tempat kerja, masa kepengurusannya bisa saja kurang dari 5 (lima) tahun. Hal ini menimbulkan ketidak efektifan dalam pengelolaan wakaf. Karena masa kerja yang singkat menjadikan pengurus BKM tidak memiliki pengetahuan yang lengkap tentang aset wakaf yang dikelola, selain itu program kerja yang telah direncanakan menjadi terhambat karena adanya pergantian atau mutasi pengurus BKM.

Sedangkan organisasi YMKP memberikan kesempatan bagi anggotanya untuk meniti karir. Karena tidak ada jabatan ex officio di YMKP. Akan tetapi ada ketentuan utama yang harus dimiliki oleh pengurus YMKP, agar bisa bertahan di YMKP, yaitu harus amanah. Menurut Aisyah, menjadi pengurus harus amanah, itu yang pertama, sebab kalau tidak amanah tidak akan diangkat sebagai pengurus. Akan tetapi memang dalam perekrutan pengurus, YMKP memprioritaskan mantan pengurus Masyumi, atau anak keturunannya, de-

22Wawancara dengan Nanang, tanggal 8 Januari 2012.

AL-AHKAM

p-ISSN: 0854-4603; e-ISSN: 2502-3209

Volume 26, Nomor 1, April 2016 || 103 
ngan alasan sudah mengetahui track record orang tuannya, sehingga jika orang tuanya baik, kemungkinan besar anaknya juga baik.23

\section{Memanfaatkan SDM Lokal sebagai Nazhir}

Menurut Kahf, manajer wakaf hendaknya berasal dari penduduk setempat, dimana aset wakaf itu berada, atau orang-orang yang berhak atas manfaat atau hasilnya. Dalam makalahnya Kahf menyebutnya dengan local community. ${ }^{24} \mathrm{Hal}$ tersebut untuk memaksimalkan waktu nazhir dalam mengelola aset wakaf dan memudahkan nazhir dalam mengawasi aset wakaf tersebut.

Pendapat Kahf ini sejalan dengan ketentuan pengelolaan wakaf di Indonesia. Dalam pembahasan mengenai nazhir baik, perseorangan, organisasi ataupun badan hukum, terdapat ketentuan agar salah seorang dari nazhir perseorangan, organisasi, atau badan hukum berdomisili di mana lokasi wakaf itu berada. 25

Pengelolaan BKM tidak menerapkan mahalliyah, yaitu memanfaatkan SDM lokal dimana lokasi aset wakaf tersebut berada. Semua aset wakaf yang tersebar di Kota Semarang, Kabupaten Demak, dan Kabupaten Kendal hanya dikelola oleh BKM Kota Semarang yang berada di Kota Semarang. Hal tersebut menimbulkan kerawanan, apabila pengurus BKM Kota Semarang tidak rajin meninjau lokasi tanah wakaf, akan ditempati oleh orang luar secara ilegal. Dan itu telah terjadi di beberapa tanah wakaf yang dimiliki oleh BKM Kota Semarang. Seperti tanah wakaf Bondo Masjid Besar Semarang yang berada di di kampung Gutitan, Kelurahan Sarirejo, dengan luas $2.200 \mathrm{~m}^{2}$, seluruhnya telah dihuni penduduk. Kemudian tanah wakaf bondo Masjid Besar Semarang di Kelurahan Siwalan Kecamatan Gayamsari seluas $14.695 \mathrm{~m}^{2}$, juga telah dihuni penduduk. 26

23Wawancara dengan Aisyah (mantan Ketua YMKP), tanggal 8 Januari 2014.

${ }^{24}$ Monzer Kahf, al-Waqfal-Islāmī, Tatawwuruh, Idāratuh, Tanmiyyatuh, h. 325.

25a) Pasal 4(6) PP No.42/2006 tentang Peraturan Pelaksana UU No. 41/2004 tentang Wakaf menyatakan: Salah seorang nazhir perseorangan sebagaimana dimaksud pada ayat (5) harus bertempat tinggal di kecamatan tempat benda wakaf berada; b) Pasal 7(3) PP No.42/2006 tentang Peraturan Pelaksana UU No. 41/2004 tentang Wakaf menyatakan: salah seorang pengurus organisasi harus berdomisili di kabupaten/kota letak benda wakaf berada; c) Pasal 11(3) PP No.42/2006 tentang Peraturan Pelaksana UU No. 41/2004 tentang Wakaf menyatakan: salah seorang pengurus badan hukum harus berdomisili di kabupaten/kota benda wakaf berada.

26Laporan Tim Penertiban dan Pemberdayaan Tanah BKM tahun 2010. 
YMKP memiliki nazhir yang berdomisili di kota Pekalongan dimana aset wakaf produktif tersebut berada. Selain berdomisili di tempat aset produktif tersebut berada, nazhir YMKP merupakan wakif dari tanah wakaf tersebut, sedangkan pengurus yang lain memiliki hubungan emosional dengan organisasi.

\section{Kepemimpinan}

Pengelolaan wakaf tanah yang dilakukan BKM Kota Semarang mengalami kevakuman, diantaranya disebabkan faktor kepemimpinan. Salah seorang pengurus BKM periode 2008-2013 mengatakan bahwa pengurus BKM periode 2008-2013 selain membawa masalah tanah wakaf akibat tukar guling yang bermasalah, juga menghadapi masalah kepemimpinan. Pimpinan tidak mampu menjalin komunikasi, dengan pengurus, mantan pengurus maupun orang diluar BKM Kota Semarang, seperti Badan Pengelola Masjid Agung Semarang. Pimpinan tidak berusaha mencari solusi atas permasalahanpermasalahan yang dihadapi BKM Kota Semarang. Permasalahan di lapangan terkesan dibiarkan tanpa ada usaha untuk menyelesaikannya. Sehingga aset wakaf tidak memberikan hasil. Pimpinan kurang mampu memberi penghargaan terhadap usaha yang telah dilakukan oleh pengurus di bawahnya. Menurut pengurus tersebut, intinya yang dibutuhkan adalah pimpinan yang amanah, memiliki kemauan dan kemampuan, serta ikhlas. ${ }^{27}$

Kesalahan kepemimpinan di BKM Kota Semarang, tidak bisa 100\% ditimpakan kepada pimpinannya dalam hal ini Kepala Kantor Kementerian Agama Kota Semarang. Hal ini terkait dengan masalah sistem kepemimpinan yang sentralistik, ex officio, tidak berbasis pada kompetensi, sehingga muncul pimpinan yang tidak menguasai bidang wakaf.

Faktor kepemimpinan di YMKP merupakan faktor yang paling menonjol dalam kesuksesan pengelolaan wakaf produktif. Sosok Ibu Aisyah sebagai ketua pada periode awal dan sebagai pembina pada periode kedua, sangat menonjol dalam pengelolaan wakaf produktif YMKP. Kemampuannya dalam

\footnotetext{
27Wawancara, tanggal 11 Agutus 2014.
} 
berkomunikasi baik ke dalam maupun ke luar, memotivasi dan ikut terlibat langsung dalam pengembangan wakaf YMKP, membuat pengurus YMKP menjadi solid, dan bekerja dengan baik. Karena kesepuhannya, beliau sangat dihormati oleh pengurus yang lain.

Menurut Stoner ada dua kriteria pemimpin yang efektif, yaitu pemimpin yang berfungsi menyelesaikan tugas atau memecahkan masalah dan yang berfungsi memelihara kelompok atau sosial. Fungsi tersebut tidak harus kedua-duanya dimiliki oleh seorang pemimpin, akan tetapi dapat diperoleh dengan kepemimpinan bersama: satu orang (biasanya manajer atau pemimpin formal) melakukan fungsi tugas, sedangkan anggota yang lain melakukan fungsi sosial. ${ }^{28}$

Kepemimpinan di BKM tidak berjalan efektif, karena pemimpinnya belum berhasil menyelesaikan tugas atau masalah yang dihadapi atau menjaga kelompok atau sosial. Kelompok di luar BKM Kota Semarang belum berhasil diajak negosiasi terkait pengelola tanah wakaf, bahkan terkesan bahwa BKM Kota Semarang ditinggal oleh kelompok lain. Hal tersebut dapat dirasakan, dengan susahnya BKM Kota Semarang untuk mengajak pihak-pihak yang berkepentingan duduk bersama menyelesaikan permasalahan tanah wakaf dan pengembangannnya.

YMKP memiliki kepemimpinan yang efektif karena berhasil menyelesaikan tugas-tugas yang direncanakan dan tetap memelihara hubungan dengan pengurus atau masyarakat di luar YMKP. Hal tersebut tercermin dengan pendistribusian hasil wakaf yang dilakukan YMKP berupa bantuan untuk sekolah-sekolah minim, dan animo masyarakat untuk menginap di Hotel Syari'ah masih berlangsung dengan lancar.

\section{Pengawasan}

Fungsi pengawasan merupakan hal yang penting dalam pengelolaan wakaf. Terry dalam Sujamto menyatakan bahwa pengawasan adalah untuk menentukan apa yang telah dicapai, mengadakan evaluasi atasannya, dan

28 James A. F. Stoner, dkk, Manajemen, jilid 2, h. 165. 
mengambil tindakan-tidakan korektif bila diperlukan untuk menjamin agar hasilnya sesuai dengan rencana. ${ }^{29}$ Menurut Kahf pengawasan yang baik bila dilakukan oleh Pemerintah dan masyarakat. 30

Dalam struktur organisasi, di BKM Kota Semarang tidak ada unsur pengawas, sedangkan YMKP memiliki unsur pengawas. Walaupun BKM Kota Semarang tidak memiliki unsur pengawas, akan tetapi karena organisasi BKM Kota Semarang adalah organisasi vertikal, maka BKM Kota Semarang berkewajiban memberikan laporan tahunan kepada BKM Propinsi Jawa Tengah. Apabila BKM Propinsi menindaklanjuti laporan tahunan tersebut maka ini merupakan bentuk pengawasan.

UU Wakaf telah mengatur adanya unsur pengawasan eksternal oleh Pemerintah dan masyarakat, sebagaimana dalam pasal 56 ayat 1-3, yang berbunyi: 1) Pengawasan terhadap perwakafan dilakukan oleh Pemerintah dan masyarakat, baik aktif maupun pasif; 2) Pengawasan aktif dilakukan dengan melakukan pemeriksaan langsung terhadap nazhir atas pengelolaan wakaf, sekurang-kurangnya sekali dalam setahun; 3) Pengawasan pasif dilakukan dengan melakukan pengamatan atas berbagai laporan yang disampaikan nazhir berkaitan dengan pengelolaan wakaf.

Adapun pengawasan yang telah dilakukan Pemerintah terhadap pengelolaan tanah wakaf produktif di BKM Kota Semarang dan YMKP masih bersifat pasif. Berdasarkan wawancara dengan nazhir BKM Kota Semarang dan YMKP, mereka hanya mengirimkan laporan kepada Kementerian Agama, bukan Kementerian Agama yang turun melakukan pengawasan aktif.

BKM Kota Semarang tidak melibatkan masyarakat sebagai pengawas harta wakaf yang dikelola, misalnya dengan meminta akuntan publik untuk mengaudit kinerja dan keuangan BKM Kota Semarang, sedangkan YMKP melibatkan masyarakat dalam pengawasan harta wakaf dengan meminta akuntan publik untuk mengaudit keuangan YMKP.

${ }^{29}$ Sujamto, Beberapa Pengertian di bidang Pengawasan (Jakarta: Ghalia Indonesia, 1986), h. 17.

30Monzer Kahf, al-Waqfal-Islāmī, Tațawwuruh, Idāratuh, Tanmiyyatuh, 2006, h. 313. 
Ahmad Furqon

Dari paparan mengenai manajemen organisasi BKM Kota Semarang dan YMKP, dapat disimpulkan bahwa manajemen organisasi BKM Kota Semarang pada tiap-tiap fungsinya tidak berjalan dengan efektif. Sedangkan manajemen organisasi YMKP telah berjalan cukup efektif. Tidak efektifnya manajemen organisasi BKM Kota Semarang dalam mengelola wakaf, memuncukan kembali diskursus mengenai pengelolaan wakaf oleh Pemerintah atau non Pemerintah.

Beberapa pakar wakaf mempermasalahkan pengelolaan wakaf oleh Pemerintah. Mereka berpendapat bahwa negara tidak mampu mengelola wakaf. Kahf, ${ }^{31}$ Habib Ahmed, ${ }^{32}$ Rizq, ${ }^{33}$ mempermasalahkan pengelolaan wakaf oleh Pemerintah, mereka mengusulkan pengelolaan wakaf harus dilakukan oleh swasta bukan oleh Pemerintah. Peran Pemerintah hanya sebagai fasilitator dan pengawas nazhir wakaf. Al-Ashqar ${ }^{34}$ berdasarkan penelitiannya tentang institusi wakaf di Barat, menyimpulkan bahwa pengelola wakaf hendaknya adalah lembaga independen yang bukan dari Pemerintah maupun sektor khusus (profit oriented). Lembaga wakaf hendaknya berasal dari masyarakat dengan memanfaatkan potensi lokal, dan untuk keluarga.

Akan tetapi al-Umar menilai bahwa institusi nazhir Pemerintah dapat mengelola wakaf dan ada juga yang berhasil dalam mengelola wakaf. Dengan syarat melibatkan masyarakat dalam kepengurusannya untuk menjamin terjadinya proses check and balance, dan bekerjasama dengan institusi profesional di bidang investasi wakaf yang akan dikembangkan. Ia mencontohkan lembaga wakaf Pemerintah yang berhasil seperti Amānah al-'Āmah li 'lAwqāf Kuwait, Hay'āt al-Awqāf di Sarjah, dan Hay'āt al-Awqāf al-Islāmiyyah Sudan. Sedangkan apabila wakaf dikelola oleh swasta, al-Umar mengusulkan agar ada pengawasan dari Pemerintah dan pengawas independen, serta

\footnotetext{
31 Ibid., h. 310.

${ }^{32}$ Habib Ahmed, Role of Zakah and Wakaf in Poverty Alleviation (Jeddah: IDB IRTI, 2004), h. 126.

33Malihah Muhammad Rizq, al-Tațawwur al-Mu'assas li Qița'i al-Awqāffi I-Mujtama'āt al-Islāmiyah (Dirāsah Ḧālah Jumhūriyyah Mișr al-'Arabiyyah) (Kuwait: al-Amānah al-'Āmli l-Awqāf, h. 57.

34'Usamah 'Umar al-Ashqar, al-Tațawwur al-Mu'assas li Qita'i al-Awqāf fi l-Mujtama'āt alIslāmiyyah (Dirāsah Hālah Jumhūriyyah Miṣr al-Arabiyyah) (Kuwait: al-Amānah al-'Ām li I-Awqāf,
} 2007). 
diterapkan prinsip transparansi dan akuntabilitas dalam pengelolaan, dengan membuat laporan keuangan dan kegiatan secara periodik. ${ }^{35}$

\section{Investasi Wakaf BKM Kota Semarang dan YMKP}

\section{Investasi Wakaf BKM Kota Semarang}

Ada 3 (tiga) bentuk investasi yang dilakukan BKM Kota Semarang untuk memproduktifkan tanah wakaf yang dimilikinya, yaitu 1) Mengontrakkan tanah pertanian, 2) Pertokoan wakaf produktif, dan 3) Penginapan. Adapun penjelasannya sebagai berikut:

\section{Kontrak Tanah Pertanian kepada Para Petani}

Dalam Laporan BKM Kota Semarang tahun 2010, disebutkan bahwa tanah BKM di Kabupaten Demak dan Kendal yang tidak bermasalah telah dikontrakkan oleh pengurus BKM sebelumnya hingga tahun 2011. Sedangkan tanah yang belum/selesai dikontrakkan ternyata bermasalah, misalnya di Desa Werdoyo Kecamatan Dempet, penggarap sawah yang sebelumnya membayar uang sewa dengan lelang, tidak mau membayar lagi dengan alasan mereka tidak merasa menjual tanahnya kepada PT. Sambirejo. Di Desa Wonoagung Kecamatan Karang Tengah, petani meminta kompensasi karena sawah yang digarapnya berubah fungsi menjadi tambak. Padahal mereka sendiri yang merubah fungsi sawah tersebut, dari sawah menjadi tambak. ${ }^{36}$ Tanah BKM yang berada di Kendal tepatnya di Desa Tanjung Sari Kecamatan Weleri, telah disewakan kepengurusan BKM sebelumnya, hingga tahun 2011.37

Sedangkan tanah wakaf Masjid Besar Semarang yang berada di Kota Semarang, tidak mampu diproduktifkan dengan baik oleh BKM Kota Semarang. Sebagian besar tanah wakaf Masjid Besar Semarang yang berada di

35Fuad Abdullah a-Umar, Istithmār al-Amwāl al-Mawqūfah (al-Shurūṭ al-Iqtișādiyah wa IMustalzamāt al-Tanmiyah) (Kuwait: al-Amānah al-'Āmmah li 1-Awqāf, 2007).

36BKM Kota Semarang, Laporan Tahun 2010, h. 7.

37Wawancara dengan Khuwaishoh, Bendahara BKM Kota Semarang pada tanggal 05 Agutus 2012. 
Ahmad Furqon

Kota Semarang, dihuni atau digarap oleh penduduk tanpa diikat dengan perjanjian sewa atau kontrak.38 Pada tanggal 23 Mei 2011, pengelolaan tanah wakaf banda Masjid Agung Semarang diambil alih oleh Badan Pengelola Masjid Agung Semarang (BP MAS), lewat kesepakatan dengan BKM Kota Semarang disaksikan oleh walikota Semarang.

\section{Pertokoan WakafProduktif}

BKM memproduktifkan tanah wakaf dengan membangun Pertokoan Wakaf Produktif di atas tanah seluas $5000 \mathrm{~m}^{2}$. Pertokoan tersebut terletak di Jl. Soekarno-Hatta, Kelurahan Sawah Besar, Kecamatan Gayam Sari Kota Semarang. Pertokoan tersebut dibangun pada tanggal 28 Desember 2006 selama 120 hari, dan selesai diresmikan pada tanggal 6 September 2007 oleh Menteri Agama Maftuh Basyuni.

Pertokoan tersebut terdiri dari 28 unit kios. ${ }^{39}$ Investasi ini, ternyata tidak berjalan sesuai rencana. Laporan BKM tertanggal 14 Juli 2010 menyebutkan bahwa dari 28 unit kios yang dipasarkan, hanya 14 unit yang tersewa. Sedangkan selebihnya dalam keadaan kosong. Karena lama kosong, kondisi bangunan sudah mulai rusak. Banyak truk-truk yang bongkar muat dan parkir di lahan pertokoan tanpa dipungut biaya parkir. Sampai bulan Juli 2010, dari sewa kios hanya terkumpul dana Rp. 126.391.785.40 Pada tanggal 23 Mei 2011, pertokoan wakaf produktif ini juga diambil alih pengelolaannya oleh BP MAS.

\section{Wisma Sejahtera BKM Kota Semarang}

BKM Kota Semarang membangun wisma, yang bernama Wisma Sejahtera BKM Kota Semarang. Wisma Sejahtera BKM Kota Semarang terletak di kelurahan Palebon Kecamatan Pedurungan. Wisma Sejahtera menempati tanah seluas $15.388 \mathrm{~m}^{2}$ dengan bangunan seluas $500 \mathrm{~m}^{2}$.

\footnotetext{
38Laporan Tim Penertiban dan Pemberdayaan Tanah Wakaf BKM Kota Semarang, 2010.

39Direktorat Jenderal Bimas Islam, Bimas Islam Dalam Angka 2012 (Jakarta: Direktorat Jenderal Bimas Islam, 2008)

40BKM Kota Semarang, Laporan Tahun 2010.
} 
Wisma Sejahtera diresmikan pada hari Ahad, tanggal 3 Maret 1985 oleh Menteri Agama ketika itu, Munawir Sadzali. Pada masanya, wisma sering dipakai oleh Kementerian Agama Provinsi dan Kota, sekolah-sekolah agama serta universitas-universitas untuk pelatihan-pelatihan. Wisma sudah mulai tidak dipergunakan sejak lengsernya Suharto pada tahun 1998 sampai sekarang. Tidak adanya biaya perawatan, dan tidak adanya pemasukan dari penyewaan gedung untuk perbaikan, menjadikan wisma mengalami kerusakan yang parah.

\section{Investasi Tanah Wakaf Produktif YMKP}

YMKP memproduktifkan tanah wakaf yang dimiliki dengan membangun Islamic Business Center. Islamic Business Center berlokasi di jalur utama Pantai Utara atau tepatnya di jalan Gajah Mada No.5. Jalan yang sangat strategis karena merupakan jalan utama di Kota Pekalongan dan jalan yang menghubungkan Pekalongan dengan kota-kota di sekitarnya. Di depan Islamic Business Center terdapat stasiun kereta api Kota Pekalongan.

Islamic Business Center memiliki 3 (tiga) jenis usaha produktif, yaitu: Hotel Syari'ah, ruko dan toko, serta warung kuliner/resto. Adapun penjelasan dari masing-masing unit usaha produktif tersebut adalah sebagai berikut:

\section{Hotel Syariah}

Peletakan batu pertama pembangunan Hotel Syariah pada tanggal 26 Desember 2006 dan diresmikan penggunaannya oleh Menteri Agama RI Maftuh Basyuni pada akhir bulan Desember 2007. Hotal ini mulai dioperasikan pada bulan April 2008.41

Hotel Syariah merupakan unit usaha wakaf produktif terbesar dibandingkan unit-unit usaha produktif lainnya yang dikelola oleh YMKP. Hotel Syariah juga merupakan ikon gedung bisnis center, sebagaimana yang tertera dalam misi Hotel Syariah. Adapun alasan pemilihan Hotel Syariah sebagai bentuk investasi tanah wakaf YMKP adalah karena hasil dari studi kelayakan usaha yang

41Wawancara dengan Nanang, Manejer Hotel Syariah, tanggal 8 Januari 2012. 
dilakukan oleh YMKP dengan melihat posisi tanah yang berada di depan stasiun kereta api, dan di sekitarnya juga telah berdiri hotel. Akan tetapi agar memiliki perbedaan dengan hotel-hotel sekitarnya, maka dipilihlah ide Hotel Syariah. ${ }^{42}$

Hotel ini memiliki 17 kamar. Kamar-kamar memiliki spesifikasi yang berbeda-beda. Mulai dari VIP, double room, dan single room. Kamar-kamar dinamai dengan nama tempat-tempat pelaksanaan haji seperti Safa, Marwa, Arafa, dan Mina.

Pengelola Hotel Syariah berkeyakinan bahwa label syariah tidak menjadikan hotelnya menjadi sepi, akan tetapi akan tetap diminati, karena masing-masing hotel sudah ada segmentasinya. Label syariah membawa misi syiar, dan predikat hotel wakaf, dapat menjadi penarik minat bagi masyarakat untuk menginap di hotel syariah. Karena dengan menginap di Hotel Syariah, berarti masyarakat sekalian beramal, karena keuntungan yang diperoleh akan dipergunakan untuk tujuan sosial. Berbeda dengan hotel lain yang hanya berorientasi profit. ${ }^{43}$

Pada tahun 2010, pendapatan YMKP dari pengelolaan Hotel Syari'ah adalah sebesar Rp. 719.860.750,00. Sedangkan dari penyewaan gedung pertemuan, YMKP mendapatkan keuntungan sebesar Rp. 38.555.000,00.44 Pada tahun 2013, pendapatan YMKP dari Hotel Syariah adalah sebesar Rp.560.367.000. Sedangkan dari gedung pertemuan mendapatkan pemasukan sebesar Rp.13.950.000,-..45

Dari laporan pemasukan Hotel Syari'ah yang dikelola oleh YMKP, terlihat ada grafik penurunan pendapatan. Penurunan pendapatan tersebut menurut Nur Rochmah, akunting merangkap resepsionis Hotel Syariah, disebabkan munculnya pesaing baru, yaitu Hotel Horison yang memiliki 102 kamar, dan Hotel Santika yang mempunyai Sembilan lantai dengan 104 kamar. $^{46}$

42Wawancara dengan Nofel, mantan Sekretaris YMKP, tanggal 8 Januari 2012.

43Wawancara dengan Aisyah, mantan Ketua YMKP, tanggal 8 Januari 2012.

${ }^{44}$ Laporan Tahunan YMKP tahun 2011.

45Fakultas Ekonomi Universitas Pekalongan 2013. Laporan Audit Keuangan YMKP.

46Wawancara dengan Nur Rochmah, Resepsionis Hotel Syariah, tanggal 8 Januari 2015.

112 || Volume 26, Nomor 1, April 2016

AL-AHKAM p-ISSN: 0854-4603; e-ISSN: 2502-3209 


\section{Toko dan Ruko}

Unit usaha lain yang dikelola oleh YMKP di atas tanah wakaf yang merupakan bagian dari Islamic Business Center adalah 1 ruko dan 4 toko. Ruko dan toko tersebut berdiri di depan Hotel Syari'ah, di depan jalan utama secara langsung. Ruko dan toko diinvestasikan dalam bentuk penyewaan kepada masyarakat yang berminat. Tiap-tiap toko disewakan dengan harga Rp.8,5 Juta rupiah pertahun, rata-rata penyewa menyewa selama 2 (dua) tahun. Sedangkan ruko disewakan dengan harga Rp. 10 juta pertahun. Karena posisinya yang strategis, toko dan ruko laris disewa. ${ }^{47}$ Pada tahun 2010, pemasukan dari penyewaan toko dan ruko adalah sebesar Rp. 42.000.000,-.48 Harga sewa ruko dan toko yang ditetapkan oleh cukup murah apabila melihat pertimbangan lokasi yang strategis. Sehingga masih memungkinkan untuk di naikkan sesuai dengan harga pasar.

\section{Restoran Kuliner}

Unit usaha wakaf produktif lain yang dikelola YMKP di atas tanah wakaf adalah usaha restoran kuliner yang dikelola langsung oleh YMKP. Restorannya bernama Restoran Thayyibah. Restoran ini menyediakan menu makanan khas Pekalongan seperti soto tauto, nasi megono dan masakan-masakan khas Jawa lainnya. Konsumen dari restoran kuliner ini adalah dari tamu Hotel Syari'ah dan masyarakat yang sengaja mampir untuk menikmati masakan di restoran kuliner Thayyibah.

Pada laporan keuangan tahun 2010, pemasukan YMKP dari pengelolaan restoran kuliner Thayyibah adalah Rp. 101.638.700,-. Akan tetapi pada laporan keuangan tahun 2013, pemasukan YMKP dari restoran kuliner Thayyibah mengalami menurun yang drastis, yaitu menjadi Rp. 26.856.960,-.

Faktor penyebabnya berhubungan dengan menurunnya tingkat hunian Hotel Syari'ah yang berimbas pada menurunnya pendapatan pada unit usaha restoran kuliner, karena sebagian besar pembeli restoran kuliner adalah tamu

\footnotetext{
47Wawancara dengan Aisyah, mantan ketua YMKP, tanggal 8 Januari 2012.

48Laporan Tahunan YMKP tahun 2010.
} 
Ahmad Furqon

atau keluarga dari tamu yang menginap di Hotel Syari'ah. Karena tamu yang menginap semakin berkurang, maka konsumen restoran kuliner juga berkurang. ${ }^{49}$

\section{Kesimpulan}

Berdasarkan pembahasan di atas, dapat disimpulkan beberapa hal sebagai berikut: Pertama, manajemen organisasi BKM Kota Semarang tidak berjalan dengan efektif pada tiap-tiap fungsinya. Pada aspek perencanaan, BKM tidak merencakanakan dengan realistic dan attainable, sehingga program-program kerja yang dibuat banyak yang tidak terlaksana. Pada aspek pengorganisasian, pengelolaan BKM tidak didasarkan pada spesialisasi kerja, tidak berbasis penilaian, tidak memanfaatkan SDM lokal. Pada aspek kepemimpinan, pemimpin BKM Kota Semarang tidak mampu menyelesaikan tugas atau masalah dan tidak mampu memelihara hubungan dengan internal dan eksternal. Pada aspek pengawasan, yang dilakukan adalah pengawasan pasif bukan pengawasan aktif, sehingga terkesan hanya melaksanakan formalitas pelaporan, tanpa ada perubahan atau perbaikan. Sedangkan manajemen organisasi YMKP telah berjalan cukup efektif, akan tetapi pada penunjukan nazhir berbasis penilaian atau kompetensi dan motivasi perlu menjadi perhatian YMKP. Penunjukan berbasis kompetensi akan melahirkan profesionalisme dan inovasi, sedangkan motivasi berupa insentif bagi pengurus perlu dilakukan karena adanya keinginan dari sebagian pengurus untuk diadakanya insentif untuk meningkatkan kinerja.

Kedua, investasi dan distribusi hasil wakaf tanah yang dilakukan oleh BKM Kota Semarang tidak produktif. Investasi yang dilakukan tidak mendapatkan hasil yang diharapakan, bahkan dipertengahan jalan investasi yang dilakukan diambil alih oleh pihak lain. Investasi yang dilakukan oleh YMKP mendapatkan hasil yang produktif, hal tersebut dikarenakan usaha yang dilakukan dapat dijalankan dengan baik ditambah dengan pemilihan jenis usaha dan lokasi usaha yang baik.

49Wawancara dengan Nur Rochmah, tanggal 8 Januari 2015. 
Ketiga, faktor yang menyebabkan kegagalan BKM Kota Semarang dalam mengelola wakaf tanah produktif adalah karena faktor internal dan eksternal. Adapun faktor internal berupa manajemen yang tidak efektif dan ketiadaan dana. Sedangkan faktor eksternal berupa kondisi sebagian tanah wakaf yang masih dipersengketakan atau ditempati secara illegal oleh masyarakat, dukungan masyarakat yang rendah, serta adanya keterlibatan pihak lain yang mengelola tanah wakaf seperti BP. MAS, dan MAJT. Keberhasilan YMKP dalam mengelola wakaf juga karena faktor internal dan eksternal. Faktor internal adalah berupa manajemen yang cukup efektif. Sedangkan faktor eksternal berupa dukungan kepercayaan dari masyarakat, serta lokasi tanah wakaf yang strategis.[a]

\section{DAFTAR PUSTAKA}

Ahmed, Habib, Role of Zakah and Wakaf in Poverty Alleviation, Jeddah: IDB IRTI, 2004.

al-Ashqar, 'Usamah 'Umar, Tațīr al-Mu'assasah al-Waqfiyyah al-Islāmiyyah fi Daw' al-Tajribah al-Khairiyyah al-Gharbiyyah, Kuwait: al-Amānah al'Āmmah li 'l-Awqāf, 2007.

al-Ashqar, 'Usamah 'Umar, al-Tatawwur al-Mu'assas li Qita'ì al-Awqāf fi ' "Mujtama'āt al-Islāmiyyah (Dirāsah Hālah Jumhüriyyah Mișr al'Arabiyyah), Kuwait: al-Amānah al-'Ām li 'l-Awqāf, 2007.

al-Umar, Fuad Abdullah, Istithmār al-Amwāl al-Mawaūfah (al-Shurūt alIqtisādivah wa '1-Mustalzamāt al-Tanmiyah), Kuwait: al-Amānah al'Āmmah li 'l-Awqāf, 2007.

BKM Kota Semarang, Laporan Tahun 2010.

Direktorat Ienderal Bimas Islam, Bimas Islam Dalam Angka 2012, Jakarta: Direktorat Jenderal Bimas Islam, 2008.

Fakultas Ekonomi Universitas Pekalongan, Laporan Audit Keuangan YMKP.

Handoko, T.Hani, dkk, Manajemen dalam Berbagai Perspektif, Jakarta: Erlangga, 2012.

Kahf, Monzer, Al-Waqf al-Islāmī, Tațawwuruh, Idāratuh, Tanmiyyatuh, Suriah: Dār al-Fikr, 2006.

Laporan Tim Penertiban dan Pemberdayaan Tanah BKM tahun 2010.

Laporan Tim Penertiban dan Pemberdayaan Tanah Wakaf BKM Kota Semarang, 2010. 
Ahmad Furqon

Rizq, Malihah Muhammad, al-Tatawwur al-Mu'assasī li Qitāài al-Awqāf fi 'lMujtama'āt al-Islāmiyah (Dirāsah Hālah Jumhūriyyah Mișr al-'Arabiyyah) (Kuwait: al-Amānah al-'Ām li 'l-Awqāf, t.th.

Sedarmayanti, Pengembangan Kepribadian Pegawai, Bandung: Penerbit Mandar Maju, 2004.

Siagian, Sondang P. Organisasi Kepemimpinan dan Perilaku Administrasi, Jakarta: CV. Haji Mas Agung, 1998.

Sinungan, Muchdarsyah, Produktivitas apa dan Bagaimana, Jakarta: Bumi, 2000.

Stoner, James A. F., dkk, Manajemen, alih bahasa Alexander Sindoro, Jilid I, Jakarta: PT. Prenhallindo, 1996.

Sujamto, Beberapa Pengertian di bidang Pengawasan, Jakarta: Ghalia Indonesia, 1986.

Wawancara dengan Arifin (Pengurus BKM Kota Semarang, tanggal 17 Februari 2012, jam 20.00, di rumah Palebon Raya Semarang.

Wawancara dengan Taufik Rahman, tanggal 8 Agustus 2012.

Wawancara dengan Aisyah, tanggal 8 Januari 2012.

Wawancara dengan Nanang, tanggal 8 Januari 2012.

Wawancara dengan Aisyah (Mantan Ketua YMKP), tanggal 8 Januari 2014.

Wawancara dengan Khuwaishoh, Bendahara BKM Kota Semarang pada tanggal 05 Agutus 2012.

Wawancara dengan Nofel, Mantan Sekretaris YMKP, tanggal 8 Januari 2012.

Wawancara dengan Nanang, Manejer Hotel Syariah, tanggal 8 Januari 2012.

Wawancara dengan Aisyah, Mantan Ketua YMKP, tanggal 8 Januari 2012.

Wawancara dengan Nur Rochmah, Resepsionis Hotel Syariah, tanggal 8 Januari 2015.

Wawancara dengan Aisyah, mantan ketua YMKP, tanggal 8 Januari 2012.

Wawancara dengan Nur Rochmah, tanggal 8 Januari 2015.

Wawancara, tanggal 23 Mei 2011.

Wawancara, tanggal 15 Mei 2012.

Wawancara, tanggal 11 Agutus 2014.

Williams, Chuck, Manajemen (terj), Jakarta: Salemba Empat, 2001.

http://www.suaramerdeka.com, diakses tanggal 22 Juli 2012.

116 || Volume 26, Nomor 1, April 2016

AL-AHKAM

p-ISSN: 0854-4603; e-ISSN: 2502-3209 